\title{
Persiapan Laktasi pada Ibu Hamil di Puskesmas Pakuan Baru Kota Jambi
}

\author{
Ria Febrina \\ Program Studi SI Kebidanan dan Profesi Ners, STIKes Baiturrahim Jambi \\ Email:febrinaria2002@gmail.com
}

Submitted : 15/12/2020

Accepted: 08/01/2022

Published: 28/01/2022

\begin{abstract}
The World Health Organization (WHO) recommends giving exclusive breast milk (ASI) for 6 months. Breast milk is a source of nutrition with a balanced composition and adjusted to the baby's growing needs. Global exclusive breastfeeding in 2017 was 38\%. WHO targets that by 2025 there will be an increase in exclusive breastfeeding by 50\%. The achievement of exclusive breastfeeding in Indonesia is $65.16 \%$, not yet reaching the target figure of $80 \%$. Exclusive breastfeeding coverage in Jambi Province reached 68.64\%, while exclusive breastfeeding coverage at Pakuan Baru Health Center was $73.04 \%$ from the target of $80 \%$. The unachieved coverage of exclusive breastfeeding is influenced by many factors, including low knowledge of lactation management and lack of information to mothers and their families about the importance of exclusive breastfeeding. Therefore, it is necessary to provide education to increase the knowledge of mothers about exclusive breastfeeding, which is started during pregnancy. It is hoped that when the mother gives birth, the mother can breastfeed her baby exclusively. The implementation time is in July 2020. The target of this community service is pregnant women who visit the Pakuan Baru Community Health Center. Community service methods include survey and counseling approaches. The results obtained are that pregnant women understand about exclusive breastfeeding and are willing to give exclusive breastfeeding to their babies. It is recommended that the Puskesmas maintain the extension program related to exclusive breastfeeding that has been given
\end{abstract}

Keywords: breast milk exclusive, breastfeeding counseling,pregnant women.

\begin{abstract}
Abstrak
World Health Organization (WHO) merekomendasikan pemberian Air Susu Ibu (ASI) eksklusif selama 6 bulan. ASI merupakan sumber gizi dengan komposisi yang seimbang dan disesuaikan dengan kebutuhan pertumbuhan bayi. Pemberian ASI eksklusif secara global pada tahun 2017 sebesar 38\%. WHO menargetkan pada tahun 2025 ada peningkatan pemberian ASI eksklusif sebesar 50\%. Capaian ASI eksklusif di Indonesia sebesar 65,16\%, belum mencapai angka target yaitu sebesar 80\%. Cakupan ASI eksklusif di Provinsi Jambi mencapai 68,64\% sedangkan cakupan ASI eksklusif di Puskesmas Pakuan Baru sebesar 73,04\% dari target sebesar 80\%. Belum tercapainya cakupan ASI eksklusif dipengaruhi banyak hal diantaranya rendahnya pengetahuan tentang manajemen laktasi dankurangnya informasi pada ibu dan keluarga mengenai pentingnya pemberian ASIeksklusif. Maka dari itu diperlukan pemberian edukasi untuk meningkatkan pengetahuan ibu tentang ASI eksklusif yang mulai diberikan sejak masa kehamilan., diharapkan saat ibu melahirkan ibu dapat menyusui bayinya secara eksklusif. Waktu pelaksanaan dilakukan pada bulan Juli 2020. Sasaran dalam pengabdian masyarakat ini adalah ibu hamil yang berkunjung di Puskesmas Pakuan Baru. Metode pengabdian masyarakat meliputi pendekatan survei dan konseling. Hasil yang diperoleh adalah ibu hamil memahami mengenai ASI eksklusif dan mau memberikan ASI eksklusif pada bayinya. Disarankan kepada pihak Puskesmas untuk mempertahankan program penyuluhan terkait ASI eksklusif yang sudah diberikan.
\end{abstract}

Kata Kunci : ASI, ibu hamil, konseling asi eksklusif 


\section{PENDAHULUAN}

Membangun sumber daya manusia (SDM) yang berkualitas merupakan salah satu tujuan pembangunan nasional agar dapat melanjutkan perjuangan pembangunan nasional menuju masyarakat sejahtera, adil dan makmur.

Pembentukan manusia yang berkualitas dimulai sejak bayi dalam kandungan disertai dengan pemberian ASI sejak dini, terutama ASI eksklusif. Pemberian ASI berarti memberikan zat-zat gizi yang bernilai tinggi yang dibutuhkan untuk pertumbuhan dan perkembangan syaraf dan otak, memberikan zat-zat kekebalan terhadap beberapa penyakit dan mewujudkan ikatan emosional antara ibu dan bayinya (Roesli, 2005).

World Health Organization (WHO) merekomendasikan agar setiap bayi mendapatkan ASI eksklusif pada 6 bulan pertama kehidupan (WHO, 2018). United Nations Children's Fund (UNICEF)menyatakan bayi yang diberikan susu formula memiliki kemungkinan untuk meninggal dunia pada bulan pertama kelahirannya dengan peluang 25 kali kali lebih tinggi dibandingkan bayi yang diberi ASI eksklusif (Journal Paediatric, 2006).

Capaian ASI eksklusif di Indonesia $65,16 \%$, belum mencapai angka target yaitu sebesar 80\%. Cakupan ASI Eksklusif di Provinsi Jambi mencapai 68,64 \% (Profil Kesehatan Indonesia 2018). Cakupan ASI eksklusif di Puskesmas Pakuan Baru sebesar 63,69 \% juga belum mencapai target sebesar 80\% (Dinkes Kota Jambi, 2018).

Faktor-faktor yang mempengaruhi pemberian ASI eksklusif pada bayi menurut hasil penelitian Arifiati (2017) adalah faktor pekerjaan, pengetahuan, dukungan keluarga serta dukungan tenaga kesehatan.

Upaya pemerintah dalam meningkatkan ASI eksklusif adalah mengadakan program yang dilakukan rutin oleh tim kesehatan seperti tenaga kesehatan puskesmas antara lain melakukan kelas ibu hamil di puskesmas masing-masing, serta kegiatan konseling yang diberikan oleh konselor yang memiliki sertifikat kepada para catin, ibu hamil dan ibu menyusui.

Konseling merupakan satu kegiatan yang dilakukan untuk membantu petugas kesehatan terutama untuk para bidan,perawat dan dokter dalam membantu ibu untuk mendapatkan informasi dalam pemberian ASI. Tujuan dilaksanakan konseling adalah untuk melatih para petugas kesehatan meningkatkan keterampilan dasar pemberian ASI. Cara memberikan dukungan dan semangat ibu untuk memberikan ASI eksklusif (Amiruddin, 2008).

Salah satu faktor yang mempengaruhi pemberian ASI eksklusif adalah pengetahuan. Pengetahuan yang benar tentang ASI eksklusif akan meningkatkan capaian ASI eksklusif dan anak-anak akan dapat tumbuh secara optimal.

Berdasarkan alasan diatas maka perlu diberikannya edukasi mengenaiASI eksklusif sebagai upaya untukmeningkatkan pengetahuan serta pencapaian pemberian ASI eksklusif.

\section{TARGET DAN LUARAN}

1. Target

Target dalam kegiatan pengabdian kepada masyarakat ini adalah ibu hamil yang berkunjung ke Puskesmas Pakuan Baru.

\section{Luaran}

Adapunluaran kegiatan pengabdian masyarakat ini selain publikasi pada jurnal ilmiah yaitu:

a. Pemahaman ibu hamil tentang ASI eksklusif.

b. Serta peningkatan capaian ASI eksklusif.

\section{METODE PELAKSANAAN}

Kegiatan pengabdian kepada masyarakat dilaksanakan pada bulan Juli 2020 dengan sasaran kegiatan adalah ibu hamil berjumlah 8 orang. 
Tahapan kegiatan pengabdian kepada masyarakat meliputi:

A. Persiapan

1. Sosialisasi: pertemuan dengan pihak puskesmas Pakuan Baru.

2. Mengidentifikasi masalah.

3. Permusuan solusi : menyampaikan rencana kegiatan kepada pihak Puskesmas dengan mengurus surat izin melakukan kegiatan pengabdian kepada masyarakat.

B. Pelaksanaan

1. Melakukan pretest (menggali pemahaman ibu hamil tentang ASI eksklusif).

2. Memberikan konseling tentang ASI eksklusif (pengertian, manfaat, komposisi ASI, persiapan menyusui sejak kehamilan dan posisi menyusui).

3. Diskusi dan tanya jawab.

4. Monitoring dan evaluasi

\section{HASIL DAN PEMBAHASAN}

Kegiatan pengabdian masyarakat ini bertujuan agar sejak dari masa hamil ibu sudah dapat memahami mengenai ASI eksklusif, agar ibu hamil siap dan dapat menyusui anaknya secara eksklusif. Pada pengabdian ini ibu hamil diberikan konseling tentang ASI eksklusif. Kegiatan konseling berlangsung kurang lebih 10-15 menit per orang dan terlaksana dengan tertib dan lancar serta mendapat antusias yang baik dari para peserta dan pihak puskesmas. Kegiatan yang dilakukan adalah memberikan edukasi kesehatan berupa konseling ASI eksklusif yangmeliputi pengertian, manfaat ASI eksklusif , komposisi ASI, persiapan menyusui sejak kehamilan dan posisi menyusui.

Pendidikan kesehatan merupakan suatu proses untuk menyadarkan, meningkatkan pengetahuan dan merubah perilaku masyarakat tentang kesehatan. Pendidikan kesehatan bertujuan agar masyarakat menyadari dan mengetahui cara memelihara kesehatan, menghindari atau mencegah dari hal-hal yang merugikan kesehatan serta bagaimana mencari pengobatan yang tepat (Notoatmojo, 2007). Pemberian konselingdiharapkan dapat meningkatkan pengetahuan ibu hamil tentang ASI eksklusif dan mau menyusui bayinya secara eksklusif.

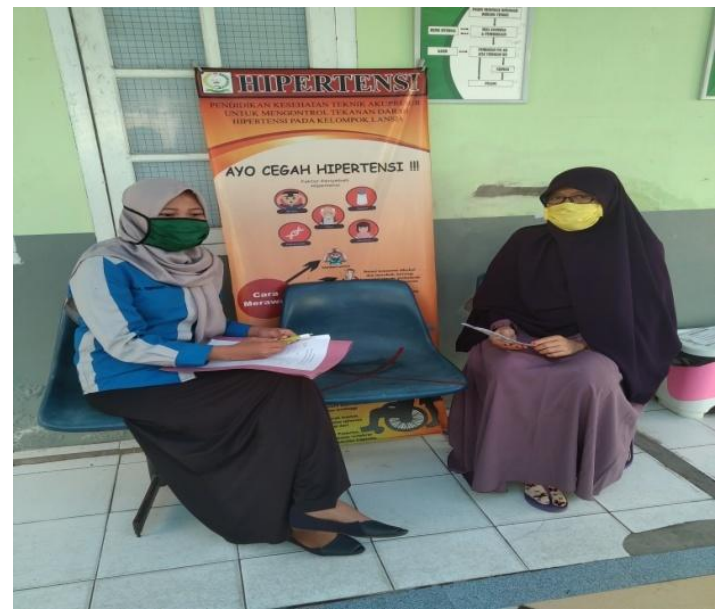

Gambar 1. Konseling ASI Eksklusif

ASI memiliki manfaat yang sangat banyak untuk bayi. Pemberian ASI berarti memberikan zat-zat gizi yang bernilai tinggi yang dibutuhkan untuk pertumbuhan dan perkembangan syaraf dan otak, memberikan imunitas terhadap beberapa penyakit dan dapat mewujudkan ikatan emosional antara ibu dan bayinya. ASI merupakan satu-satunya makanan yang paling sempurna untuk menjamin tumbuh kembang bayi pada 6 bulan pertama (Roesli, 2005).

Ibu yang menyusui anaknya secara eksklusif dapat membantu anak-anak bertahan hidup dan membentuk antibodi yang dibutuhkan agar terlindungan dari berbagai penyakit yang sering terjadi pada masa kanak-kanak, seperti diare dan penumonia. Peningkatan angka ibu menyusuisecara global berpotensi menyelamatkan nyawa lebih dari 820.000 anak usia balita dan dapat mencegah penambahan 20.000 kasus kanker payudara pada perempuan setiap tahunnya (WHO, 2020). 
Satu dari dua bayi di Indonesia yang berusia di bawah 6 bulan yang mendapatkan ASI eksklusif, lebih dari $40 \%$ bayi diperkenalkan makanan pendamping terlalu dini yaitu sebelum bayi berusia 6 bulan (WHO, 2020).

UNICEF dan WHO menghimbau pemerintah untuk mendukung praktek menyusui secara berkesinambungan dn optimal dengan cara memprioritaskan layanan dan program untuk melindungi, mempromosikan, dan mendukung pemberian ASI eksklusif, memberikan dukungan kepada ibu menyusui melalui peningkatan konseling yang berkualitas dan penyediaan informasi yang akurat tentang ASI eksklusif (WHO, 2020).

Hal ini sejalan dengan hasil Kucukoglu \& Celebioglu (2014) yang menyatakan bahwa pemberian konseling ASI eksklusif dapat meningkatkan keberhasilan ASI eksklusif. Didukung oleh Gusti, dkk (2011) dimana konseling dapat meningkaykan pengetahuan dan sikap ibu terhadap ASI eksklusif.

Pemberian edukasi dan pendampingan ibu saat masa nifas perlu untuk tetap dilakukan, agar dapat memantau ibu untuk menyusui anaknya secara eksklusif selama 6 bulan dan dilanjutkan sampai anak berusia 2 tahun.

\section{KESIMPULAN DAN SARAN}

\section{Kesimpulan}

Pelaksanaan pengabdian kepada WUS di Puskesmas Pakuan Baru berjalan dengan baik. Ibu hamil mulai mengerti dan memahami mengenai ASI eksklusif dan berencana akan menyusui anaknya secara eksklusif.

\section{Saran}

Diharapkan pihak puskesmas dapat secara rutin memberikan pendidikan kesehatan terkait ASI eksklusif dan dalam memberikan konseling sebaiknya meningkatkan kualitas materi, media dan metode yang digunakan.

\section{UCAPAN TERIMAKASIH}

Ucapan terimakasih kami sampaikan kepada Sekolah Tinggi Ilmu Kesehatan Baiturrahim Jambi yang telah memfasilitasi kegiatan ini, dan tak lupa kepada semua pihak yang telah membantu kegiatan kepada masyarakat ini.

\section{DAFTAR PUSTAKA}

Arifiati, Nurce. 2017. Analisis faktor yang mempengaruhi pemberian ASI eksklusif pada bayi di Kelurahan Warnasari Kecamatan Citangkil Kota Cilegon. Prosiding seminar nasional IKAKESMADA "peran tenaga kesehatan dalam pelaksanaan SDGs", 129-135, 2017. Eprints.uad.ac.id.

Dinas Kesehatan Kota Jambi. 2018. Laporan Tahunan Dinas kesehatan Kota Jambi. Jambi.

Gusti, D., \& Group, C. 2011. Promosi ASI Eksklusif Memakai Metode Konseling dengan Penyuluhan Terhadap Pengetahuan dan Sikap Ibu Menyusui, 6(94), 4-9

Kucukoglu, S., \& Celebioglu, A. 2014. Effect of Natural-Feeding Education on Successful Exclusive BreastFeeding and Breast-Feeding SelfEfficacy of Low-Birth-Weight Infants, 24(1), 49-56

Notoatmodjo, S. 2010. Promosi Kesehatan dan Ilmu Perilaku. Jakarta: Rineka Cipta

Roesli, U. 2005. Mengenal ASI Eksklusif. Jakarta: Trubus Agriwidya

World Health Organization (WHO). 2016. ASI Eksklusif. South-East Asia Indonesia.Diunduh dari https://www.who.int/indonesia/news/ detail/03-08-2020 